\title{
An Ediacaran opportunist? Characteristics of a juvenile Dickinsonia costata population from Crisp Gorge, South Australia
}

\author{
Lily M. Reid, ${ }^{1,2}$ Diego C. García-Bellido,,3 and James G. Gehling ${ }^{2,3}$ \\ ${ }^{1}$ School of Natural and Built Environments, University of South Australia, Mawson Lakes, South Australia 〈lily.reid@mymail.unisa.edu.au〉 \\ ${ }^{2}$ South Australian Museum, North Terrace, Adelaide, South Australia 〈Jim.Gehling@ samuseum.sa.gov.au〉 \\ ${ }^{3}$ School of Biological Sciences, University of Adelaide, North Terrace, Adelaide, South Australia 〈Diego.Garcia-Bellido@adelaide.edu.au〉
}

\begin{abstract}
Despite 70 years of study, Dickinsonia remains one of the Ediacara biota's most enigmatic taxa with both morphological characters and phylogenetic affinities still debated. A large population of relatively small Dickinsonia costata present on a semi-contiguous surface from the Crisp Gorge fossil locality in the Flinders Ranges (South Australia) provides an opportunity to investigate this taxon in its juvenile form. This population supports earlier findings that suggest $D$. costata's early growth was isometric, based on the relationship between measured variables of length and width. The number of body units increases with length, but at a decreasing rate. A correlation between a previously described physical feature, present as a shrinkage rim partially surrounding some specimens and a novel, raised lip in some specimens, suggests that both features may have been the result of a physical contraction in response to the burial process, rather than due to a gradual loss of mass during early diagenesis. A marked protuberance in $15 \%$ of the population is also noted in limited specimens within the South Australian Museum collections and appears to be present only in juvenile D. costata. Both the abundance and narrow size range of this population support the notion that Dickinsonia was a hardy opportunist, capable of rapid establishment and growth on relatively immature textured organic-mat substrates.
\end{abstract}

\section{Introduction}

The Ediacara biota (575-541 Myr) represent the first appearance of complex, macroscopic life on Earth, and body plan diversity spans a broad array from discs and tubes to quilted and fractal forms. Taxonomic affinities and life histories of many of these organisms remain either controversial or poorly understood. The genus Dickinsonia has been the subject of near-continual debate since it was first described 70 years ago (Sprigg, 1947). Descriptive and molecular-informed studies have sought to place Dickinsonia into various metazoan groups, as well as other kingdoms. Interpretations range from a pelagic cnidarian (Sprigg, 1947; Valentine, 1992) and polychaete worm (Glaessner and Wade, 1966; Wade, 1972) to benthic placozoan (Sperling and Vinther, 2010) and ctenophore (Zhang and Reitner, 2006). Taphonomic and morphological arguments have been used to place Dickinsonia in the proposed kingdom Vendobionta as a serially quilted unicellular organism (Seilacher et al., 2003), or as a ground-dwelling lichen (Retallack, 2007). Other studies have focused on Dickinsonia's unique, serially repeating body plan to estimate oxygen requirements, most recently demonstrating that adequate oxygenation may have been achieved via surficial diffusion (see Runnegar, 1982; Gooden, 2014). This body plan has also been utilized to suggest Dickinsonia was a bilaterian-grade animal, due to interpreted growth via the terminal addition of units from a posterior growth region (Runnegar, 1982; Gold et al., 2015). Most recently, growth models have been employed to infer a eumetazoan affinity for Dickinsonia via studies suggesting both terminal (Evans et al., 2017) and pre-terminal (Hoekzema et al., 2017) addition of body units. The identification of resting traces associated with several individual specimens indicates that it may have fed on the underlying microbial mat substrate via basal surface absorption (Gehling et al., 2005; Sperling and Vinther, 2010; Ivantsov, 2011).

This study focuses on a population of Dickinsonia costata Sprigg, 1947 from Crisp Gorge, South Australia (Fig. 1). The Crisp Gorge population comprises $53.5 \%$ of the total abundance on the semi-contiguous surface (Reid et al., 2017), and provides an excellent opportunity to study this taxon in its juvenile form. The remainder of the community comprises seven taxa and the biogenic sedimentary structure 'Mop' (Tarhan et al., 2010). Three additional taxa on the surface are also interpreted as juvenile: Parvancorina minchami Glaessner, 1958, Tribrachidium heraldicum Glaessner, 1959, and a single specimen of Rugoconites enigmaticus Glaessner and Wade, 1966. The Textured Organic Surface (TOS) components of the microbial mat substrate include a range of structures, including round, deep relief bosses and regions of TOS components including 'groove' and 'weave' (Gehling and Droser, 2009). The overall fossil surface, however, is relatively smooth, and is interpreted as immature (Reid et al., 2017).

\section{Geologic setting}

In South Australia, the Ediacara Member marks the fossiliferous shallow marine, deltaic succession of the Rawnsley Quartzite. 


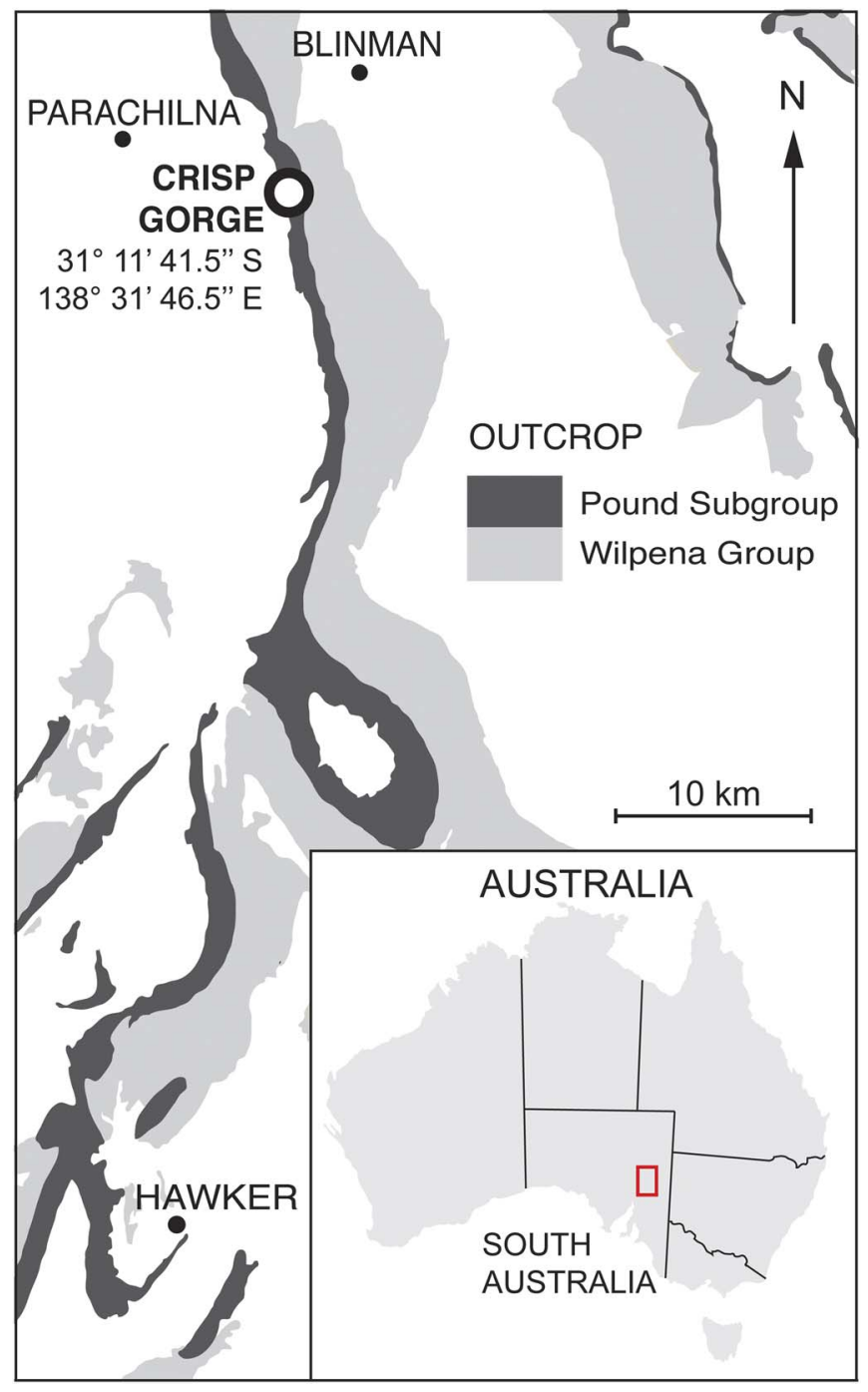

Figure 1. Locality map of the Flinders Ranges and Crisp Gorge fossil site. The Crisp Gorge fossil site is located within the Ediacara Member of the Pound Subgroup.

The Rawnsley Quartzite is the terminal package of Ediacaranaged sediments within the Pound Subgroup of the Adelaide Rift Complex (Gehling and Droser, 2012). The Ediacara Member incorporates a number of fossiliferous facies, ranging from shore-face settings, to deeper water delta-front or pro-delta environments (Gehling and Droser, 2013). By far the richest, in situ, fossil assemblages are found within the Oscillation Rippled Sandstone facies (Tarhan et al., 2017). These comprise medium- to coarse-grained feldspathic sands with distinctive rippled bed-tops, representative of a depositional environment between fair-weather and storm wave bases.

Locality information.-The Crisp Gorge fossil locality $\left(31^{\circ} 11^{\prime} 41.5^{\prime \prime S}, 138^{\circ} 31^{\prime} 46.5^{\prime \prime E}\right.$, Fig. 1) is primarily composed of repeating units of the Oscillation Rippled Sandstone facies (ORSF) and the deeper water Flat Laminated to Linguoid Rippled Sandstone facies, the latter indicative of a delta-front to pro-delta setting (Tarhan et al., 2017). Both facies are present at this locality as interbedded dark red to maroon sands and silts, with the ORSF exhibiting characteristic bed-top combined-flow ripples and several bed partings revealing a silt layer up to $3 \mathrm{~mm}$ thick (Reid et al., 2017). The majority of the sample material examined for this study was removed from the Crisp Gorge fossil locality and now forms a framed rock wall in the 'First Life: Ediacara Biota Gallery' of the South Australian Museum. This material is referred to as the 'Crisp Wall' throughout this study. The Crisp Wall surface is comprised of 16 semicontiguous slabs of medium- to coarse-grained feldspathic sandstone from the ORSF and gives a surface area of $\sim 6.5 \mathrm{~m}^{2}$. A further seven fossiliferous slabs determined to be semicontiguous with the bedding surface of the existing Crisp Wall slabs have been identified at the Crisp Gorge fossil site and are incorporated into this study.

\section{Materials and methods}

The Dickinsonia costata specimens identified on the Crisp Wall, combined with the newly identified Crisp Gorge slabs, yielded a total of 150 specimens suitable for analysis. All measurements and observations were made from positiverelief, latex casts taken from the Crisp Wall specimens to aid identification of otherwise negative-relief features and allow for the use of a dissecting microscope. For the purpose of this study, phylogenetically neutral labels are used to describe a number of morphological features of the studied $D$. costata. This is to aid in the identification of features, while avoiding ambiguity or incidental taxonomic affinities that may be inferred from using body terms usually associated with animals. The terms 'A-end' and 'B-end' are used to refer to either end of the specimens as defined by the placement of a midline, with the A-end characterized by the terminal A-end unit (Fig. 2.1). The B-end is located at the opposite end of the body, and is defined by decreasing unit size (Fig. 2.1).

Measurements for each specimen included the maximum length, as the longest distance between A- and B-ends of the specimen, maximum width, taken as the widest measure perpendicular to the midline, and the number of units. Unit counts were not taken for individuals with damaged or indistinct units, defined here as those individuals with any form of mechanical damage to the rock or sand grains that mold them, and/or those that are indistinct from neighboring units. Measurements and unit counts were made with the aid of calipers and a dissecting microscope. Observations also were made of three body features, which have been termed the A-end lip, A-end protuberance, and shrinkage rim (see Results for details).

Statistical analysis of the D. costata population was performed using the open access statistical software program PAST (Hammer et al., 2001). A Model II (major axis) regression was used in the analysis of body size (Legendre and Legendre, 1998). A rose diagram of axial orientation was produced using the open access statistical software programs $\mathrm{R}$ (RCoreTeam, 2015) and RStudio (RStudioTeam, 2015), and the package 'circular' (Lund and Agostinelli, 2015). Pairwise correlations among three observed features (A-end lip, shrinkage rim, and A-end protuberance) were calculated using the Pearson method for the presence-absence data collected. Significance of relationships was calculated using Chi-squared tests with Yates' continuity correction. To test if the $D$. costata 

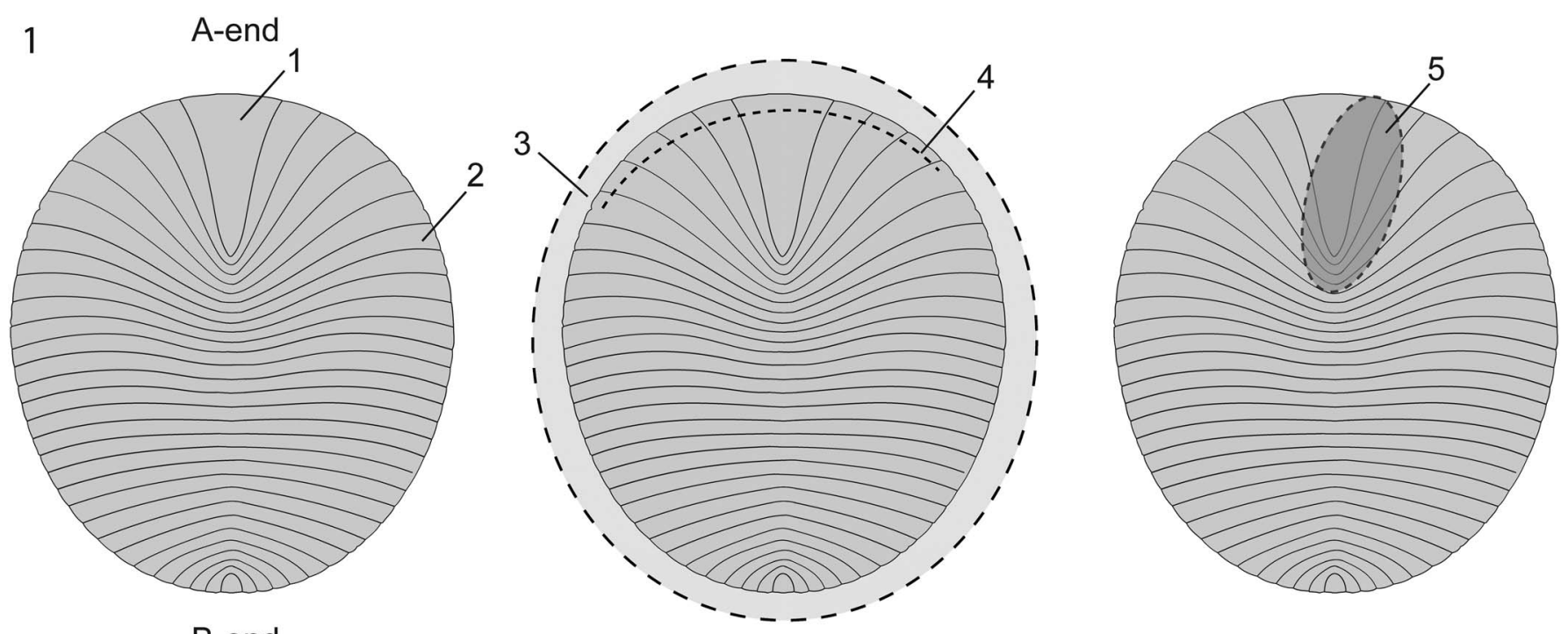

B-end
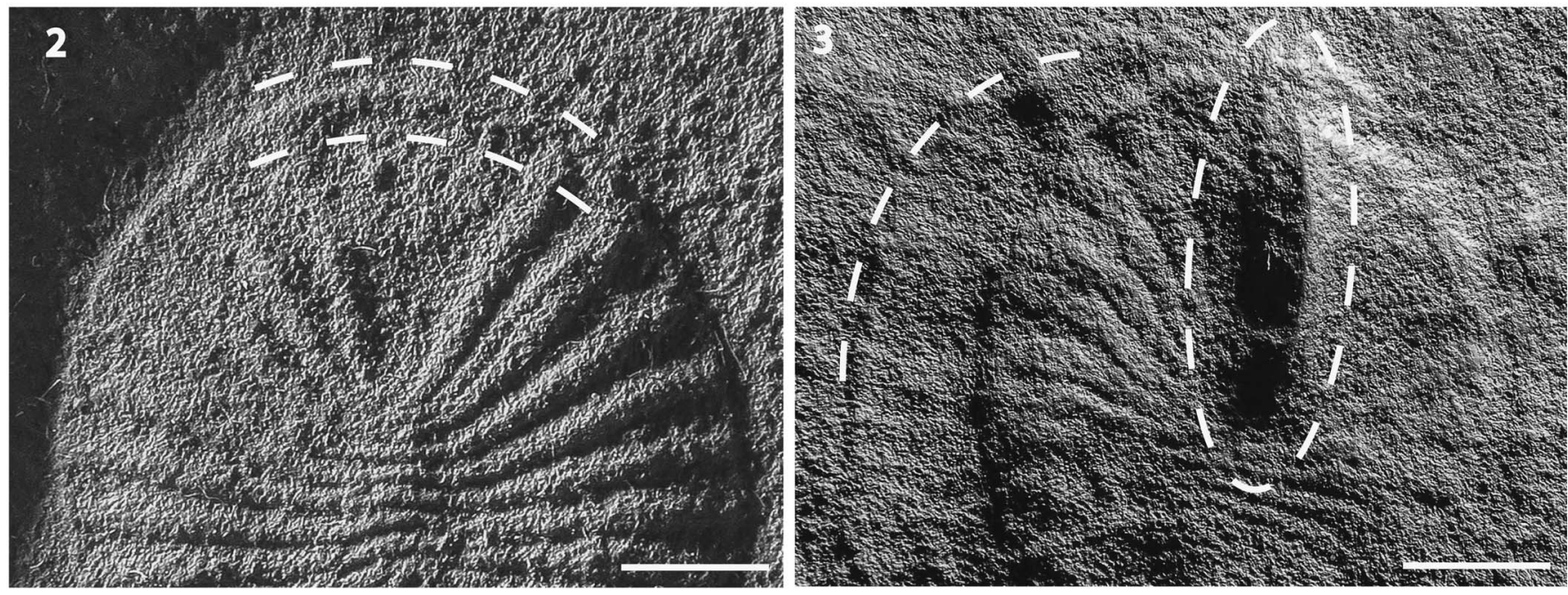

Figure 2. (1) Descriptive labels for Dickinsonia costata features: $1=$ terminal A-end unit, $2=$ body unit, $3=$ position of shrinkage rim, $4=$ position of A-end lip, $5=$ generalized position of A-end protuberance. (2) Detail of A-end lip feature, visible as a narrow, raised rim on the peripheral margin of the terminal A-end unit, SAMP34228. (3) Detail of shrinkage rim feature as an uneven margin exterior to the body fossil, and the A-end protuberance as a high relief, elongate structure involving the terminal A-end unit and several A-end units, SAMP34232. The surface visible is assumed to be the upper surface. Scale bars $=3 \mathrm{~mm}$.

size distribution was best described by a single or multiple normal distributions, we fitted univariate Gaussian finite mixture models to specimen length using the function 'Mclust' from the R package 'mclust' (Fraley et al., 2012), and compared these by optimization (minimization) of the Bayesian Information Criterion (BIC).

Repository and institutional abbreviation.-The majority of specimens examined in this study are housed in the paleontology collections of the South Australia Museum, Adelaide, Australia (Prefix SAMP), and are currently on display in the "First Life: Ediacara Biota Gallery". The remainder of specimens are located at the Crisp Gorge fossil locality. Specimens figured (Figs. 2, 4) are SAMP32351, SAMP34219, SAMP34224, SAMP34228, SAMP34232, SAMP34235, SAMP34243, SAMP34254 and SAMP34326. Please see Appendix A for the complete list of examined specimens and data set.

\section{Results}

Population size and shape.-Dickinsonia costata is constructed of repeated, parabolic units intersecting a narrow medial axis. The terminal A-end unit forms a deep V-shape, most noticeable in larger specimens; the curve of subsequent A-end units decreases towards the mid-point of the body. Units intersect the midline and no offset in units across the midline is observed. The midline lies perpendicular to units at the mid-point of the body. Preservation quality ranges from very good, in which all units are clearly visible, to poor, in which there is very little to no differentiation evident between A- and B-ends. Several specimens contained damaged or indistinct units and were excluded from unit-count data. All specimens are preserved in negative hyporelief and occupy a narrow size range, well below typical maximum size for $D$. costata (individuals may reach $25 \mathrm{~cm}$ in length). Specimens are $6.3-26.7 \mathrm{~mm}$ long, with a mean length of $13.28 \mathrm{~mm}$, and are $5.8-22.7 \mathrm{~mm}$ wide, with a mean width of 

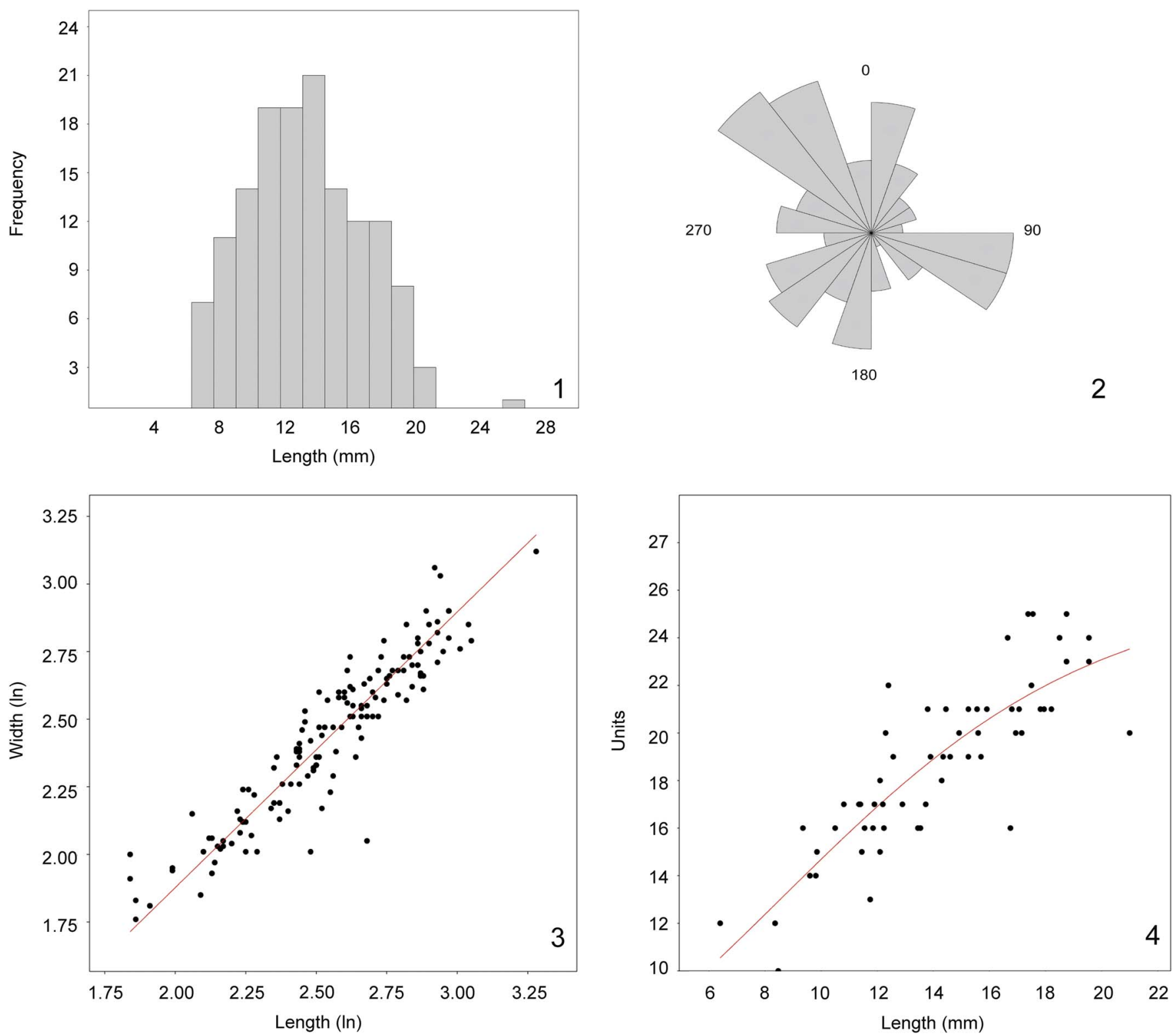

Figure 3. Analyses of Dickinsonia costata population. (1) Histogram showing size distribution of population $(\mathrm{N}=140)$; (2) rose diagram showing axial alignment of specimens $(\mathrm{N}=118)$; the ' 0 ' is an arbitrary reference and denotes the top of the "Crisp Wall" frame; $(\mathbf{3})$ graph depicting the relationship between (ln) length and $(\mathrm{ln})$ width of specimens $(\mathrm{N}=140) ;(4)$ logistic graph depicting the relationship between specimen length and number of observable units $(\mathrm{N}=58)$.

$11.86 \mathrm{~mm}$. The major axis regression of $(\ln )$ length against $(\ln )$ width produced a regression slope of 1.019 , with a $95 \%$ C.I. of $(0.953,1.089)$, which is not significantly different from one (Fig. 3.3). If a log-log model is best described by a straight line with slope (the allometric coefficient) equal to one, this suggests isometric growth (Hammer and Harper, 2006). This appears to be the case in D. costata over the size range examined (Runnegar, 1982; Evans et al., 2017). Comparisons between the linear and several non-linear models using the Akaike Information Criterion (AIC) suggested that a linear model was the best fit for these data (Fig. 3.3; Table 1). Unit number against length was best characterized by models that showed an increase in unit number with size, but at a decreasing rate (particularly for larger specimens). Of those tested, a logistic model best fitted the data based on the AIC (Fig. 3.4; Table 1). This suggests an upper limit on the number of units in D. costata, (Evans et al., 2017; Hoekzema et al., 2017).
Table 1. Akaike information criterion (AIC) values for the body-size variables of Dickinsonia costata from Crisp Gorge, Flinders Ranges. Length = body length, width $=$ body width, units $=$ number of observable body units. The relationship between body ( $(\mathrm{ln})$ length and (ln) width is best described by a linear function, suggesting isometric growth. Number of body units present against length is best described by a nonlinear, logistic model.

\begin{tabular}{lcc}
\hline & \multicolumn{2}{c}{ AIC Values } \\
\cline { 2 - 3 } Function & $(\ln )$ width $\sim(\ln )$ length & units $\sim$ length \\
\hline Linear & 5.73 & 205.83 \\
Quadratic & 7.81 & 199.11 \\
Power & 7.80 & 201.69 \\
Logistic & 7.80 & 197.89 \\
Gompertz & 7.80 & 198.9 \\
\hline
\end{tabular}

The size frequency histogram, produced using body length measurements (Fig. 3.1), describes the population distribution of D. costata from the Crisp Wall slabs and supplementary field 
material as normal (Shapiro-Wilk; $\mathrm{W}=0.98 ; \mathrm{p}=0.07$ ). A singlecomponent Gaussian finite mixture model best fitted the body length data based on optimization of the BIC, suggesting that these data are best described by a single distribution (rather than multiple distributions).

Axial orientation and paleocurrent direction.-Based on primary ripple shape and orientation of the bed top surfaces of the Crisp Wall, a primary paleocurrent direction of $\sim 55^{\circ}$ from north has been established (Reid et al., 2017). No consistent axial orientation is observed in the Crisp Wall specimens (Fig. 3.2). Hence, there appears to be no relationship between the axial orientation of $D$. costata and either paleocurrent or burial flow direction.

Morphological features.-A marked A-end protuberance occurs in $15 \%$ of the Crisp Gorge specimens (Figs. 2, 4). Broadly confined to the terminal A-end unit, this asymmetric bulge appears in deep negative relief relative to the surrounding organism, often developing into a point towards the peripheral margin. Larger protuberances extend for up to $5 \mathrm{~mm}$, in smaller specimens encompassing nearly half the sagittal length. In larger specimens where greater detail is visible, protuberances often observed to be offset from the primary axis, to either the left or the right, towards and sometimes encompassing A-end units. This feature is observed in five other small Dickinsonia within the South Australian Museum collections. The deep relief and consistent positioning of the protuberance exclude the possibility that it is the result of the organism overlying a TOS feature within the substrate.

The A-end lip appears as a raised, upper-surface rim in nearly half (45\%) of observed specimens (Figs. 2, 4). It is visible as a rim that outlines the body through the outer margin of the units at a thickness of no more than $1 \mathrm{~mm}$. It occurs most commonly through the A-end and mid-body units, and is visible on some specimens distorting the peripheral margins of individual units.

A 'shrinkage rim' feature occurs in 38\% of Crisp Gorge specimens, appearing as a positive relief rim extending $1-2 \mathrm{~mm}$ from the peripheral margin and in contrast to the negative hyporelief of the body mold (Figs. 2, 4). In most specimens, it does not extend the full circumference of the body. In some instances, however, a pronounced continual peripheral rim surrounds the body and can contain a secondary outline, interpreted as representing a second stage of shrinkage (Gehling et al., 2005). In several specimens where shrinkage is most marked, a faint impression of lower-surface units is visible within the shrinkage rim. A test of correlations between these two features shows a weak, but significant, positive relationship between the occurrence of a shrinkage rim and an A-end lip (Pearson's correlation coefficient $=0.22$, $p$-value $<0.01$ ).

\section{Discussion}

The abundance and narrow size distribution of the juvenile population on the Crisp Wall surface suggest that Dickinsonia costata may have been an opportunistic species that established on this surface shortly after deposition and stabilization of the underlying substrate (Reid et al., 2017). Dickinsonia is noted throughout all of the fossiliferous facies of the Ediacara Member in a broad range of sedimentary environments and at a range of localities, although more commonly in adult size ranges and usually at lower abundances (Droser and Gehling, 2015; Evans, 2015) than those observed in the Crisp Wall. At the Nilpena fossil locality on the western border of the Flinders Ranges, Dickinsonia is the third most abundant body fossil, exceeded only by Funisia and Aspidella, repectively, both of which represent anchored taxa (Gehling and Droser, 2013).

Opportunistic species display a range of identifying characteristics, many of which are demonstrated by Dickinsonia. They are typically generalists, capable of survival within a broad range of environmental and physiological parameters, as demonstrated by the identification of Dickinsonia in all fossiliferous facies of the Ediacara Member, and in situ within the majority of these paleoenvironments (Gehling and Droser, 2013). Species utilizing such a life history strategy may display a rapid increase in population numbers, often evidenced by the numerical domination of a given community or the rapid colonization of substrate previously devoid of organisms (Levinton, 1970). Dickinsonia comprises $>50 \%$ of the Crisp Wall community, a trait that is not uncommon in other Ediacara Member communities (Droser and Gehling, 2015).

The Crisp Wall population displays minimal variance in size and is normally distributed, in contrast with other observed D. costata populations. Broadly speaking, Dickinsonia records a right-skewed population and a spread of body sizes spanning juvenile to adult (Zakrevskaya, 2014; Evans, 2015). There are two potential reasons for this discrepancy: (1) this population was the result of a single, isolated reproductive event; and (2) this population was buried in the very early stages of continuous or recurring, episodic recruitment, but was too immature to record a bimodal, clustered, or skewed distribution. Regardless, the distribution of this juvenile population does not negate the likelihood of longer-term continuous recruitment within the taxon, and supports the notion that the Crisp Wall surface records an immature, pioneer-stage community (Reid et al., 2017).

Based on the length to width ratio, Dickinsonia costata displays a juvenile isometric growth pattern (Fig. 3.3). This is consistent with previous findings, which have focused on larger individuals of the taxon and suggest that overall growth was isometric, with length and width increasing at a steady ratio throughout the majority of the organism's lifecycle (Runnegar, 1982; Evans et al., 2017). This is despite the observed decrease in unit addition, indicating that overall shape is maintained independent of unit number (Evans et al., 2017; Hoekzema et al., 2017). Although all specimens are broadly ovoid in shape, variation in shape does occur. This may be accounted for by flexibility of the organism, and may be related to flexure resulting from movement of the organism in relation to the underlying microbial substrate. It may also be due to natural variation within the population. Likewise, a minor amount of size variation may be accounted for by the presence of the shrinkage rim in organisms that display this feature.

The lack of axial orientation noted in Dickinsonia both in this study and previously is in contrast to observations made for other Ediacaran forms (see Evans et al., 2015). Several Ediacaran taxa, including Thectardis avalonensis 

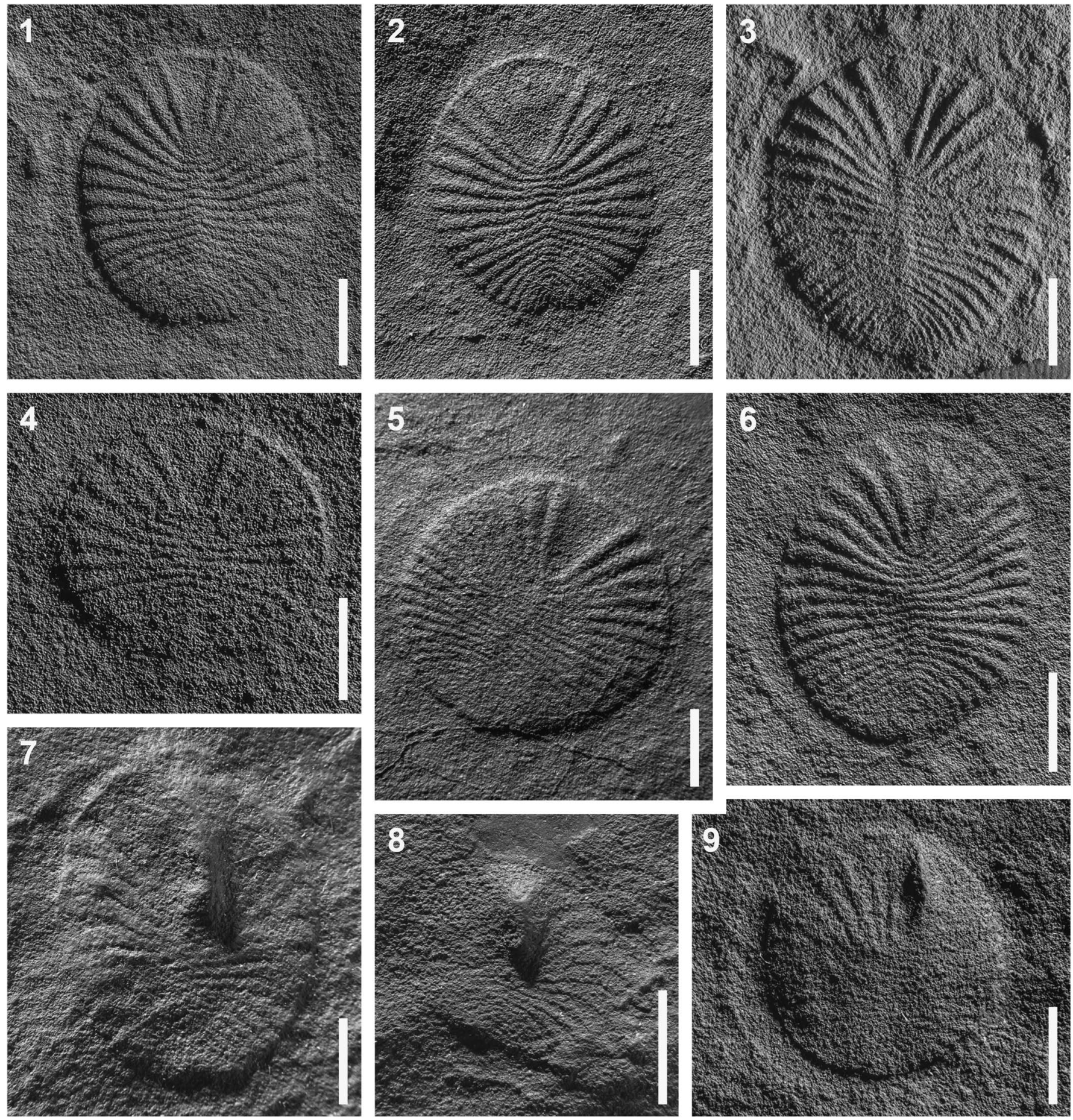

Figure 4. Photographs of Dickinsonia costata Sprigg 1947 from the Crisp Gorge fossil locality, Flinders Ranges (latex rubber casts). (1) Well-defined, non-continuous shrinkage rim and A-end lip, SAMP34235; (2) well-developed A-end lip present as narrow, high relief band in A-end units, SAMP34228; (3) continuous shrinkage rim visible around entirety of body, SAMP34243; (4) A-end lip visible on right side of body distorting perimeter of A-end units, SAMP32351; $(\mathbf{5 , 6})$ displaying continuous, uneven shrinkage rims SAMP34224, SAMP34219; $(\mathbf{7}, \mathbf{8})$ A-end protuberance present as a bold, high relief structure encompassing terminal A-end units and involving subsequent A-end units, SAMPP34232, SAMP34254; (9) A-end protuberance and shrinkage rim, SAMP34326. Scale bars $=5 \mathrm{~mm}$.

Clapham et al., 2004 and fronds, including Charnia Ford, 1958 have been demonstrated to have been manipulated by the unidirectional current flow at the time of their burial, effectively recording current direction of the burial flow with their final resting position (Wood et al., 2003; Clapham et al., 2004; Wilby et al., 2011). Recent evidence of rheotaxis in Parvancorina suggests that an active response to current flow was employed, with individuals demonstrated to align with the current within two different paleoenvironments, most likely to minimize drag and ensure that current flow was directed over feeding structures (Paterson et al., 2017; Darroch et al., 2017). The absence of current alignment in Dickinsonia may be due in part to its 
inferred life habit in near-constant contact with the underlying microbial substrate on which it likely fed (Sperling and Vinther, 2010). This close relationship with the dense, often ropey, substrate may have made Dickinsonia more or less impervious to current action, with the exception of higher-energy events lifting a small portion of the body away from the substrate (Evans et al., 2015).

The correlation between the shrinkage rim and A-end lip suggests that these features may have represented a physical response by the organism to the burial process. The shrinkage rim is also observed in Dickinsonia specimens from a number of localities across a range of sizes and has been interpreted as representing the shrinkage of the organism, due to a loss of mass associated with desiccation during early diagenesis (Gehling et al., 2005). Its correlation with the A-end lip suggests that this feature may also be due to the burial process, and that these features combined could be the result of a muscle-like contraction in response to the burial event, indicating displacement rather than loss of mass, and resulting in a thickening of the peripheral margin of the organism. The occurrence of this lip most commonly through the terminal A-end unit may be due to this unit representing the thinnest section through the fossil, and therefore making it most apparent in this location.

In contrast to these features, the striking A-end protuberance noted in this population is observed in only a limited number of small or juvenile Dickinsonia elsewhere in the South Australian Museum collections. Although broadly limited to the terminal A-end unit, placement of the protuberance within this region appears to be random. The deep-relief nature of the feature suggests that it was largely impervious to the burial process and was therefore likely constructed of the same material as the rest of the organism. Why it appears in such a high concentration in the Crisp Gorge material, but remains relatively rare in other Dickinsonia populations such as those at the Nilpena fossil locality, remains unclear. Given the juvenile size range of this population, however, it appears most likely that this feature is an artifact of early growth and may reflect a biological structure found exclusively in juveniles. Were it to be observed in a single individual, it may be dismissed as a preservational abnormality. It is unlikely, however, that this structure is taphonomic because there is nothing to suggest that the mode of preservation varied based on the size of the organism preserved.

\section{Conclusions}

The Dickinsonia costata population from Crisp Gorge provides an excellent opportunity to examine this taxon in juvenile form, and investigate the physical characteristics of such a population. Dickinsonia was likely a hardy opportunist with a single, juvenile size mode, which grew isometrically by maintaining its overall size ratio. The presence of the morphological features observed, including the shrinkage rim and A-end lip, requires further investigation in adult specimens, with the study of larger individuals perhaps providing higher-resolution material for examination. The A-end protuberance described in this population is most likely an artifact of early growth, however, further examination of juvenile Dickinsonia from other Ediacara surfaces will be helpful to confirm this.

\section{Acknowledgments}

This research has been supported by a student research grant from the University of Adelaide 2014-007, a summer research scholarship from the University of South Australia PD134814, an Australian Government Research Training Program Scholarship, and a South Australian Museum Early Career Researcher Postgraduate Scholarship to LMR. DCGB is supported by Australian Research Council Future Fellowship FT130101329. Collection and transport of the majority of material utilized in this project was funded by an NSF grant (EAR 9004601) to B.N. Runnegar. We thank C. Reschke and family for access to the Crisp Gorge locality. A. Liu and J. Holmes are thanked for field assistance and feedback. This manuscript benefited from feedback provided by M. Lee, J. Antcliffe, M. Laflamme, and J. Hoyal Cuthill.

\section{References}

Clapham, M.E., Narbonne, G.M., Gehling, J.G., Greentree, C., and Anderson, M.M., 2004, Thectardis avalonensis: a new Ediacaran fossil from the Mistaken Point biota, Newfoundland: Journal of Paleontology, v. 78, p. 1030-1036.

Darroch, S.A., Rahman, I.A., Gibson, B., Racicot, R.A., and Laflamme, M., 2017, Inference of facultative mobility in the enigmatic Ediacaran organism Parvancorina: Biology Letters, v. 13, e20170033.

Droser, M.L., and Gehling, J.G., 2015, The advent of animals: the view from the Ediacaran: Proceedings of the National Academy of Sciences, v. 112, p. $4865-4870$.

Evans, S.D., 2015, Ecology and Biology of Dickinsonia, an Iconic Member of the Ediacara Biota From Nilpena, South Australia [MSc Thesis]: Riverside, CA, University of California, Riverside, $43 \mathrm{p}$.

Evans, S.D., Droser, M.L., and Gehling, J.G., 2015, Dickinsonia liftoff: evidence of current derived morphologies: Palaeogeography, Palaeoclimatology, Palaeoecology, v. 434, p. 28-33.

Evans, S.D., Droser, M.L., and Gehling, J.G., 2017, Highly regulated growth and development of the Ediacara macrofossil Dickinsonia costata: PLoS One, v. 12, e0176874.

Fraley, C., Raftery, A.E., Murphy, T.B., and Scrucca, L., 2012, package "mclust": Version 4 for R: Normal Mixture Modeling for Model-Based Clustering, Classification, and Density Estimation, v. 5.3, https://cran. r-project.org/web/packages/mclust/index.html

Ford, T.D., 1958, Pre-Cambrian fossils from Charnwood Forest: Proceedings of the Yorkshire Geological and Polytechnic Society, Geological Society of London, v. 31, p. 211-217.

Gehling, J.G., and Droser, M.L., 2009, Textured organic surfaces associated with the Ediacara biota in South Australia: Earth-Science Reviews, v. 96, p. 196-206.

Gehling, J.G., and Droser, M.L., 2012, Ediacaran stratigraphy and the biota of the Adelaide Geosyncline, South Australia: Episodes - Newsmagazine of the International Union of Geological Sciences, v. 35, p. 236.

Gehling, J.G., and Droser, M.L., 2013, How well do fossil assemblages of the Ediacara Biota tell time?: Geology, v. 41, p. 447-450.

Gehling, J.G., Droser, M.L., Jensen, S., and Runnegar, B.N., 2005, Ediacara organisms: Relating form to function, in Briggs, D.E.G., ed., Evolving Form and Function: Fossils and Development: New Haven, CT, Yale University, p. 43-66.

Glaessner, M.F., 1958, New fossils from the base of the Cambrian in South Australia: Transactions of the Royal Society of South Australia, v. 81, p. $185-188$.

Glaessner, M.F, 1959, Precambrian Coelenterata from Australia, Africa and England: Nature, v. 183, p. 1472-1473.

Glaessner, M.F., and Wade, M., 1966, The late Precambrian fossils from Ediacara, South Australia: Palaeontology, v. 9, p. 599-628.

Gold, D.A., Runnegar, B., Gehling, J.G., and Jacobs, D.K., 2015, Ancestral state reconstruction of ontogeny supports a bilaterian affinity for Dickinsonia: Evolution and Development, v. 17, p. 315-324.

Gooden, B., 2014, Segmentation and oxygen diffusion in the ediacaran 'Dickinsonia': an applied analysis: Journal and Proceedings of the Royal Society of New South Wales, v. 147, p. 107.

Hammer, Ø., and Harper, D.A., 2006, Paleontological Data Analysis: Oxford, Wiley-Blackwell, $356 \mathrm{p}$. 
Hammer, Ø., Harper, D.A.T., and Ryan, P.D., 2001, PAST: Paleontological statistics software package for education and data analysis: Palaeontologia Electronica, v. 4, no. 1, p. 1-9 http://palaeo-electronica.org/2001_1/past/ issue1_01.htm

Hoekzema, R.S., Brasier, M.D., Dunn, F.S., and Liu, A.G., 2017, Quantitative study of developmental biology confirms Dickinsonia as a metazoan: Proceedings of the Royal Society B, v. 284, p. 20171348.

Ivantsov, A.Y., 2011, Feeding traces of proarticulata-the Vendian metazoa: Paleontological Journal, v. 45, p. 237-248.

Legendre, P., and Legendre, L., 1998, Numerical Ecology: Amsterdam, Elsevier, Developments in Environmental Modelling, v. 20, 853 p.

Levinton, J.S., 1970, The paleoecological significance of opportunistic species: Lethaia, v. 3, p. 69-78.

Lund, U., and Agostinelli, C., 2015, package "circular": Circular Statistics, v. 0.4-7, https://cran.r-project.org/web/packages/circular/circular.pdf

Paterson, J.R., Gehling, J.G., Droser, M.L., and Bicknell, R.D., 2017, Rheotaxis in the Ediacaran epibenthic organism Parvancorina from South Australia: Scientific Reports, v. 7, 45539.

RCoreTeam 2015, R: A language and environment for statistical computing: Vienna, Austria, R Foundation for Statistical Computing, https://www. r-project.org

Reid, L.M., García-Bellido, D.C., Payne, J.L., Runnegar, B., and Gehling, J.G., 2017, Possible evidence of primary succession in a juvenile-dominated Ediacara fossil surface from the Flinders Ranges, South Australia: Palaeogeography, Palaeoclimatology, Palaeoecology, v. 476, p. 68-76.

Retallack, G.J., 2007, Growth, decay and burial compaction of Dickinsonia, an iconic Ediacaran fossil: Alcheringa, v. 31, p. 215-240.

RStudioTeam 2015, RStudio: Integrated Development for R: Boston, MA, RStudio, Inc., https://www.rstudio.com

Runnegar, B., 1982, Oxygen requirements, biology and phylogenetic significance of the late Precambrian worm Dickinsonia, and the evolution of the burrowing habit: Alcheringa, v. 6, p. 223-239.

Seilacher, A., Grazhdankin, D., and Legouta, A., 2003, Ediacaran biota: the dawn of animal life in the shadow of giant protists: Paleontological Research, v. 7, p. 43-54.

\section{Appendix}

Physical characteristics and orientation of Dickinsonia costata on Crisp Gorge "wall" surface. ${ }^{1}$ Axial Orientation is measured relative to a north proxy (top horizontal bar of the Crisp Wall frame). Axial orientation was not
Sperling, E.A., and Vinther, J., 2010, A placozoan affinity for Dickinsonia and the evolution of late Proterozoic metazoan feeding modes: Evolution and Development, v. 12, p. 201-209.

Sprigg, R.C., 1947, Early Cambrian (?) jellyfishes from the Flinders Ranges, South Australia: Transactions of the Royal Society of South Australia, v. 71, p. 212-224.

Tarhan, L.G., Droser, M.L., and Gehling, J.G., 2010, Taphonomic controls on Ediacaran diversity: uncovering the holdfast origin of morphologically variable enigmatic structures: Palaios, v. 25, p. 823-830.

Tarhan, L.G., Droser, M.L., Gehling, J.G., and Dzaugis, M.P., 2017, Microbial mat sandwiches and other anactualistic sedimentary features of the Ediacara Member (Rawnsley Quartzite, South Australia): implications for interpretation of the Ediacaran sedimentary record: Palaios, v. 32, p. 181-194.

Valentine, J.W., 1992, Dickinsonia as a polypoid organism: Paleobiology, v. 18 , p. 378-382.

Wade, M., 1972, Dickinsonia: polychaete worms from the late Precambrian Ediacara fauna, South Australia: Memoirs of the Queensland Museum, v. 16, p. 171-190

Wilby, P.R., Carney, J.N., and Howe, M.P.A., 2011, A rich Ediacaran assemblage from eastern Avalonia: evidence of early widespread diversity in the deep ocean: Geology, v. 39, p. 655-658.

Wood, D.A., Dalrymple, R.W., Narbonne, G.M., Gehling, J.G., and Clapham, M.E., 2003, Paleoenvironmental analysis of the late Neoproterozoic Mistaken Point and Trepassey formations, southeastern Newfoundland: Canadian Journal of Earth Sciences, v. 40, p. 1375-1391.

Zakrevskaya, M., 2014, Paleoecological reconstruction of the Ediacaran benthic macroscopic communities of the White Sea (Russia): Palaeogeography, Palaeoclimatology, Palaeoecology, v. 410, p. 27-38.

Zhang, X., and Reitner, J., 2006, A fresh look at Dickinsonia: removing it from Vendobionta: Acta Geologica Sinica (English Edition), v. 80, p. 636-642.

Accepted 16 November 2017

measured for specimens in which orientation was indistinct. ${ }^{2}$ Width and/or length measurements are not included for specimens that were damaged or the outline of the fossil was unclear.

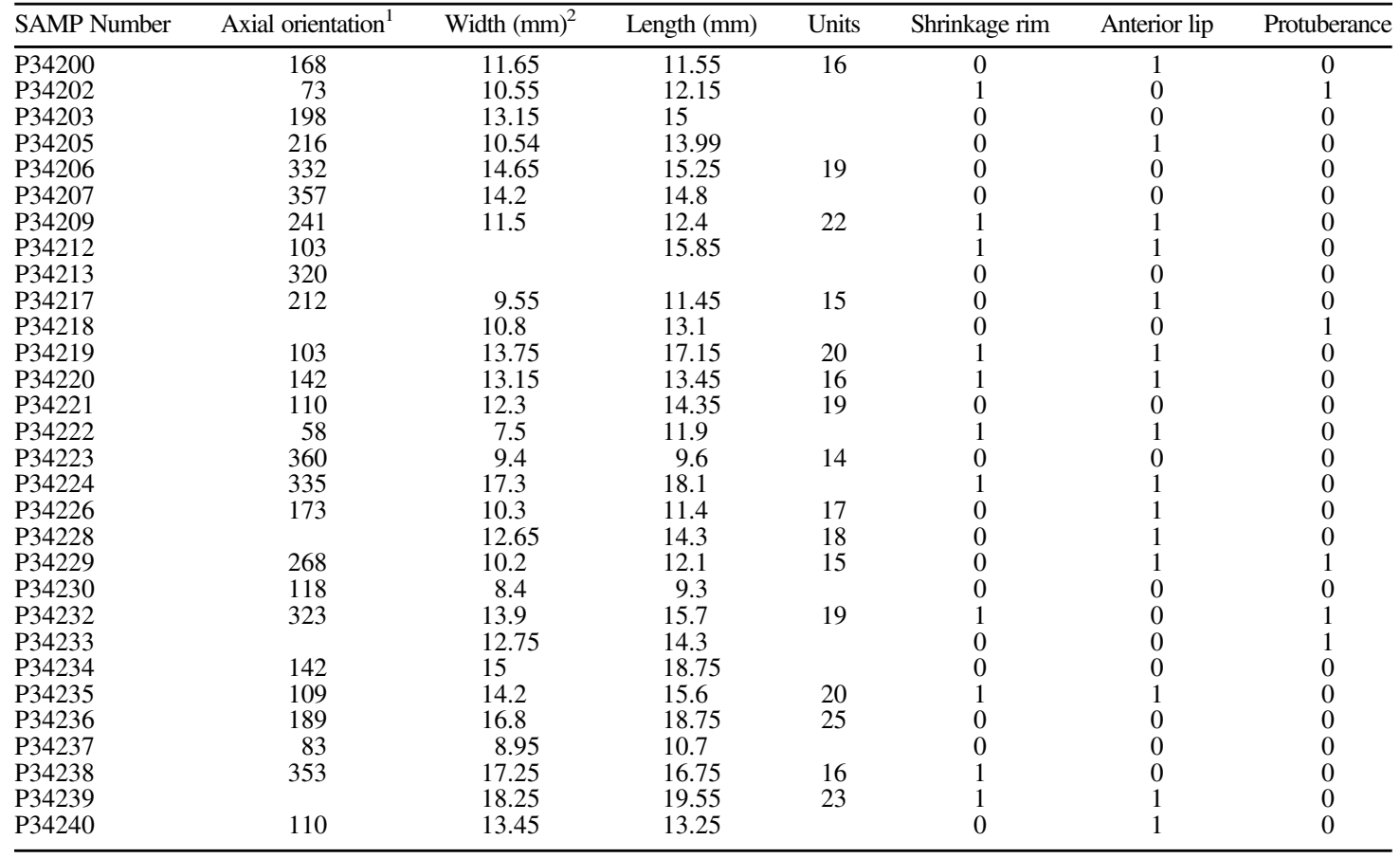


Reid et al. -Population analysis of Dickinsonia costata from South Australia

(Continued)

\begin{tabular}{|c|c|c|c|c|c|c|c|}
\hline SAMP Number & Axial orientation ${ }^{1}$ & Width $(\mathrm{mm})^{2}$ & Length (mm) & Units & Shrinkage rim & Anterior lip & Protuberance \\
\hline P34241 & 25 & 7.55 & 8.7 & & 0 & 0 & 0 \\
\hline P34242 & 204 & 12.25 & 14.65 & & 1 & 0 & 0 \\
\hline P34244 & 249 & 14.35 & 17.6 & & 1 & 1 & 0 \\
\hline P34245 & 204 & 16.4 & 17.4 & & 1 & 0 & 0 \\
\hline P34257 & 263 & 8.45 & 10.75 & & 0 & 1 & 0 \\
\hline P34258 & 213 & 16.25 & 21.1 & & 1 & 1 & 0 \\
\hline P34259 & & 12.75 & 14.6 & 19 & 1 & 1 & 0 \\
\hline P34260 & 113 & 12.75 & 13.9 & & 0 & 0 & 0 \\
\hline P34261 & 78 & 8.9 & 10.5 & 16 & 1 & 1 & 0 \\
\hline P34262 & 112 & 9.6 & 11.1 & & 0 & 1 & 0 \\
\hline P34263 & 218 & 9.35 & 9.4 & & 0 & 1 & 1 \\
\hline P34264 & 342 & 11.25 & 11.9 & 17 & 1 & 1 & 0 \\
\hline P34266 & 77 & 7.5 & 9.45 & & 0 & 1 & 0 \\
\hline P34267 & 19 & 8.35 & 9.35 & 16 & 0 & 0 & 0 \\
\hline P34268 & 188 & 18.2 & 17.95 & 21 & 1 & 0 & 0 \\
\hline P34269 & 106 & 14.65 & 16.65 & & 0 & 0 & 1 \\
\hline P34270 & & 9.9 & 11.85 & 16 & 0 & 1 & 0 \\
\hline P34277 & 347 & 13.75 & 13.8 & 21 & 1 & 1 & 0 \\
\hline P34278 & 60 & 11.8 & 14.2 & & 0 & 0 & 0 \\
\hline P34279 & & 13.55 & 13.9 & & 0 & 1 & 0 \\
\hline P34280 & 127 & 11.1 & 11.45 & & 1 & 0 & 1 \\
\hline P34281 & 326 & 10.55 & 12.3 & & 0 & 0 & 0 \\
\hline P34282 & 348 & 10.6 & 11.45 & & 0 & 0 & 0 \\
\hline P34283 & 329 & 10.55 & 10.55 & & 1 & 1 & 0 \\
\hline P34285 & 142 & 13.5 & 12.3 & 20 & 0 & 1 & 0 \\
\hline P34287 & 187 & 8.9 & 10.75 & & 0 & 1 & 0 \\
\hline P34288 & 51 & 7.65 & 8.8 & & 0 & 1 & 0 \\
\hline P34289 & 263 & 12.35 & 14.9 & & 1 & 1 & 0 \\
\hline P34291 & 347 & 11.8 & 12.3 & & 1 & 0 & 1 \\
\hline P34294 & 114 & 10.87 & 11.45 & & 0 & 0 & 0 \\
\hline P34295 & 126 & 10.85 & 11.45 & & 0 & 0 & 0 \\
\hline P34297 & 126 & 15.7 & 17.55 & 25 & 1 & 0 & 0 \\
\hline P34299 & 252 & 14.29 & 17.8 & & 0 & 0 & 0 \\
\hline P34300 & 328 & 15.35 & 13.75 & & 1 & 0 & 0 \\
\hline P34301 & 72 & 11.4 & 14.3 & & 0 & 0 & 0 \\
\hline P34302 & 321 & 11.8 & 12.9 & 17 & 0 & 1 & 0 \\
\hline P34303 & 86 & 12.3 & 15.25 & 21 & 0 & 1 & 0 \\
\hline P34304 & 67 & 13.05 & 16.8 & 21 & 0 & 0 & 1 \\
\hline P34305 & 276 & 17.45 & 18.75 & 23 & 1 & 0 & 0 \\
\hline P34312 & 270 & 18.18 & 19.55 & & 0 & 1 & 1 \\
\hline P34313 & & 6.25 & 6.45 & & 0 & 0 & 0 \\
\hline P34314 & & 6.35 & 8.1 & & 1 & 0 & 0 \\
\hline P34316 & & & & & 1 & 1 & 0 \\
\hline P34317 & 357 & 14.3 & 15.85 & & 0 & 0 & 0 \\
\hline P34318 & 263 & 8.7 & 11 & & 1 & 0 & 0 \\
\hline P34320 & & 12.6 & 11.75 & 13 & 0 & 1 & 0 \\
\hline P34321 & 224 & 16.4 & 19.55 & 24 & 0 & 0 & 0 \\
\hline P34322 & 45 & 10.1 & 12.1 & 18 & 0 & 1 & 0 \\
\hline P34323 & 137 & 7.65 & 8.6 & & 0 & 0 & 0 \\
\hline P34324 & & 5.8 & 6.4 & 12 & 0 & 0 & 0 \\
\hline P34325 & 260 & 22.65 & 26.7 & & 1 & 1 & 0 \\
\hline P34326 & 138 & 13.25 & 13.2 & & 1 & 0 & 1 \\
\hline P34327 & & 8.75 & 12.45 & & 0 & 1 & 0 \\
\hline P34328 & & 7.5 & 9.85 & 15 & 0 & 1 & 0 \\
\hline P34329 & 229 & 13.35 & 16.3 & & 1 & 0 & 1 \\
\hline P34330 & & 7.8 & 8.75 & & 0 & 1 & 0 \\
\hline P34331 & & 15.8 & 20.3 & & 1 & 0 & 0 \\
\hline P34333 & 222 & 7.9 & 9.7 & & 1 & 1 & 0 \\
\hline P34337 & 42 & 8.75 & 10.35 & & 0 & 0 & 0 \\
\hline P34339 & 73 & 12.35 & 13.9 & 19 & 0 & 1 & 0 \\
\hline P34340 & & 9.5 & & & 0 & 0 & 0 \\
\hline P34341 & 89 & 10.3 & 12.2 & 17 & 1 & 1 & 0 \\
\hline P34342 & 243 & 14.9 & 17.5 & 22 & 1 & 1 & 0 \\
\hline P34345 & 126 & 15.65 & 19.05 & & 1 & 0 & 1 \\
\hline P34346 & 179 & 8.7 & 9.25 & & 1 & 1 & 0 \\
\hline P34347 & 124 & 7.8 & 14.6 & & 1 & 1 & 0 \\
\hline P34348 & 152 & 7.45 & 8.15 & & 0 & 0 & 0 \\
\hline P34349 & & 9.3 & 12.85 & & 0 & 0 & 0 \\
\hline P34204 & & 7.03 & 7.35 & & 0 & 0 & 0 \\
\hline P34208 & 243 & 9.88 & 12.88 & & 0 & 0 & 0 \\
\hline P34210 & 330 & 12.89 & 13.54 & & 0 & 1 & 0 \\
\hline P34215 & & 7.69 & 9.03 & & 0 & 0 & 0 \\
\hline P34216 & 126 & 8.6 & 7.84 & & 0 & 0 & 0 \\
\hline P34217 & 212 & 10.32 & 12.24 & 16 & 1 & 1 & 0 \\
\hline P34225 & 158 & 15.37 & 15.32 & & 1 & 0 & 0 \\
\hline P34226 & 173 & & & & 0 & 0 & 0 \\
\hline P34227 & 262 & 17.27 & 21 & 20 & 1 & 1 & 0 \\
\hline P34231 & 291 & & & & 0 & 0 & 0 \\
\hline P34243 & 238 & 14.94 & 17.06 & 21 & 1 & 1 & 0 \\
\hline P34246 & 97 & 8.34 & 9.4 & & 0 & 0 & 0 \\
\hline
\end{tabular}


(Continued)

\begin{tabular}{|c|c|c|c|c|c|c|c|}
\hline SAMP Number & Axial orientation ${ }^{1}$ & Width $(\mathrm{mm})^{2}$ & Length (mm) & Units & Shrinkage rim & Anterior lip & Protuberance \\
\hline$\overline{\mathrm{P} 34247}$ & & 6.14 & $\begin{array}{l}6.78 \\
\end{array}$ & & 1 & 0 & 0 \\
\hline P34248 & 225 & 13.09 & 15.49 & & 1 & 1 & 1 \\
\hline P34249 & 111 & 14.58 & 15.91 & 21 & 0 & 0 & 0 \\
\hline P34250 & & 6.98 & 7.31 & & 0 & 0 & 0 \\
\hline P34251 & 156 & 16.3 & 15.56 & 21 & 0 & 1 & 1 \\
\hline P34252 & 143 & 14.64 & 13.54 & 16 & 0 & 1 & 0 \\
\hline P34253 & 153 & 10.94 & 11.35 & 17 & 0 & 1 & 0 \\
\hline P34256 & & 6.88 & 8.39 & & 0 & 0 & 0 \\
\hline P34265 & 171 & & & & 0 & 0 & 0 \\
\hline P34273 & 3 & 15.36 & 16.94 & 20 & 1 & 1 & 0 \\
\hline P34274 & 223 & 12.33 & 13.73 & 17 & 0 & 0 & 0 \\
\hline P34275 & 331 & 8.33 & 9.49 & & 0 & 0 & 0 \\
\hline P34284 & & 6.75 & 6.32 & & 0 & 0 & 0 \\
\hline P34286 & 155 & 13.5 & 13.47 & & 0 & 0 & 1 \\
\hline P34290 & & & & & 0 & 0 & 0 \\
\hline P34293 & 325 & 7.88 & 8.41 & & 0 & 1 & 0 \\
\hline P34294 & 114 & & & & 0 & 0 & 0 \\
\hline P34296 & 96 & 16.06 & 17.38 & 25 & 1 & 0 & 1 \\
\hline P34306 & 13 & 14.45 & 17.58 & & 0 & 0 & 0 \\
\hline P34307 & 78 & 7.99 & 9.32 & & 0 & 0 & 0 \\
\hline P34308 & 306 & 12.08 & 11.65 & & 1 & 1 & 0 \\
\hline P34309 & 66 & 13.54 & 17.82 & 21 & 1 & 0 & 1 \\
\hline P34310 & 328 & 7.88 & 8.36 & 12 & 0 & 1 & 0 \\
\hline P34311 & 132 & 20.7 & 18.92 & & 1 & 0 & 0 \\
\hline P34332 & 270 & & & & 0 & 0 & 0 \\
\hline P34334 & 125 & 11.82 & 12.57 & 19 & 1 & 1 & 0 \\
\hline P34335 & 213 & 13.92 & 14.45 & 21 & 0 & 1 & 0 \\
\hline P34336 & 222 & 14.52 & 16.3 & & 0 & 0 & 0 \\
\hline P34343 & 267 & 16.16 & 18.21 & 21 & 1 & 1 & 0 \\
\hline P34344 & 31 & 11.83 & 13.27 & & 0 & 1 & 0 \\
\hline P34356 & 58 & 9.55 & 10.81 & 17 & 0 & 0 & 0 \\
\hline P34357 & 287 & 7.19 & 8.47 & 10 & 0 & 0 & 0 \\
\hline P34254.1 & 168 & 7.36 & 6.3 & & 0 & 1 & 0 \\
\hline P34254.2 & 354 & 10.14 & 10.51 & & 1 & 0 & 1 \\
\hline \multicolumn{8}{|c|}{ Additional Crisp Gorge specimens } \\
\hline B6 & & 21.39 & 18.5 & 24 & 0 & 0 & 0 \\
\hline B7 & & 13.13 & 12.69 & & 0 & 0 & 0 \\
\hline $\mathrm{C} 8$ & & 13.5 & 14.92 & 20 & 1 & 1 & 0 \\
\hline C9 & & 9.17 & 9.81 & 14 & 0 & 0 & 0 \\
\hline C10 & & 10.78 & 11.35 & & 0 & 0 & 1 \\
\hline D11 & & 15.38 & 16.65 & 24 & 1 & 1 & 1 \\
\hline
\end{tabular}

